\title{
Party filiation and appointment for positions in the Brazilian federal bureaucracy (1999-2018)
}

\author{
Felix Lopez ${ }^{1}$ \\ Thiago Moreira da Silva ${ }^{2}$ \\ 1 Instituto de Pesquisa Econômica Aplicada / Diretoria de Estudos sobre o Estado, as Instituições e a Democracia, \\ Rio de Janeiro / RJ - Brazil \\ 2 Universidade do Estado do Rio de Janeiro / Instituto de Estudos Sociais e Políticos, Rio de Janeiro / RJ - Brazil
}

\begin{abstract}
How many are the top and middle-level Brazilian federal bureaucracy appointees, and to which party are they affiliated? Are there differences among presidential mandates regarding the number of these professionals and their party affiliation? This study seeks to answer these questions, by building a new database that gathers the number of party-affiliated public officials that were appointed to Cargos de Direção e Assessoramento Superior (DAS) (position of director and high level consultant). Descriptive analysis found that the proportion of party-affiliated among appointees increased during the Workers' Party (PT) governments and higher among appointed professionals that were not civil servant. The power-sharing among parties - mainly between the party of the president and the others - varies significantly according to the government. The partisan control over appointees is milder in middle-level and stronger at top-level positions. However, a minority of appointees are party members, even among the top-level bureaucracy. Therefore, we suggest that the political networks go beyond the party affiliations. To understand these networks it is necessary to reassess the role of party politics in shaping the executive agenda and enable reinterpretation of how presidents build and manage the government coalition and the support to their agenda in the legislative arena.
\end{abstract}

Keywords: political appointments - Brazil; patronage; political bureaucracy; multiparty presidentialism - Brazil.

\section{Filiações partidárias e nomeações para cargos da burocracia federal (1999-2018)}

Quantos são e a quais partidos estão filiados os nomeados para os cargos do alto e médio escalão da burocracia federal brasileira? Há diferenças entre mandatos presidenciais? Para responder essas perguntas, construímos uma base de dados inédita referente aos filiados a partidos políticos em cargos de direção e assessoramento superior (DAS). Nossa análise descritiva aponta que a proporção de filiados aumentou nos governos do Partido dos Trabalhadores (PT) e é maior entre nomeados sem vínculo com o setor público. A concentração de poder entre os partidos - principalmente entre o partido presidencial e os demais - variou de modo significativo entre presidentes. $\mathrm{O}$ controle partidário sobre os nomeados filiados é mais brando nos cargos de nível intermediário e maior nos níveis superiores. Entretanto, os filiados são minoria, mesmo nos cargos de mais alto poder político-administrativo. Por isso, sugerimos que, possivelmente, as redes de conexão política que definem os quadros da burocracia decisória também se constroem por meios extrapartidários e compreendê-las se mostra decisivo para dimensionar o peso da política partidária na burocracia ministerial e reinterpretar como o Poder Executivo constrói e gerencia a coalizão de governo e seu apoio no Poder Legislativo.

Palavras-chave: cargos de confiança; nomeações políticas; burocracia; filiações partidárias; presidencialismo de coalizão.

\section{Afiliaciones partidarias y nombramientos a cargos de la burocracia federal (1999-2018)}

¿Cuántos son y a qué partidos están afiliados los nominados para los puestos de rango superior y medio de la burocracia federal brasileña? ¿Hay diferencias entre los mandatos presidenciales? Para responder a estas preguntas, construimos una base de datos inédita referente a los afiliados a partidos políticos que ocupan cargos directivos y de asesoramiento superior (DAS). Nuestro análisis descriptivo muestra que la proporción de afiliados aumentó en los

DOI: http://dx.doi.org/10.1590/0034-761220180387x

Article received on November 13, 2018 and accepted on May 13, 2019.

ISSN: $1982-3134$ (c) (1)

[Translated version] Note: All quotes in English translated by this article's translator.

Felix Lopez is grateful for receiving funding from the Coordenação de Aperfeiçoamento de Pessoal de Nível Superior (CAPES), under Process 88881.172542 / 2018-01, during the period of this research. Both authors are grateful for the critiques and suggestions from anonymous referees at the Journal of Public Administration, as well as comments and suggestions from Frances Hagopian, Alexandre Samy, Antonio Lassance, Alexandre Gomide, Danilo Coelho and Acir Almeida. Marcos D. Burgos translated the Portuguese version of this text to English. The authors are responsible for any omissions or errors in this article. 
gobiernos del Partido de los Trabajadores (PT) y es mayor entre los nominados sin vínculo con el sector público. La concentración de poder entre los partidos - principalmente entre el partido presidencial y los demás- varió de modo significativo entre presidentes. El control del partido sobre los nominados afiliados es más moderado en los cargos de nivel medio y mayor en los rangos superiores. Sin embargo, los afiliados son minoría, incluso en los puestos de mayor poder político-administrativo. Por lo tanto, sugerimos que posiblemente las redes de conexión política que definen a los cuadros de la burocracia decisoria también se construyan por medios extrapartidarios, y comprenderlas es decisivo para dimensionar el peso de la política partidaria en la burocracia ministerial y reinterpretar cómo el Poder Ejecutivo construye y administra la coalición de gobierno y su apoyo en el Poder Legislativo.

Palabras clave: cargos de confianza; nombramientos políticos; burocracia; afiliaciones partidarias; presidencialismo de coalición.

\section{INTRODUCTION}

The most common expectation in analyses of appointments to public trust positions - "cargos de confiança" - within the federal bureaucracy assumes the dominance of party criteria. Fueling this expectation are rules that allow for the discretionary selection of thousands of positions in direct and indirect federal administration as well as the numerous political parties in the legislative arena that are eager to appoint their close allies in the bureaucracy. In the background, are the presidents of the Republic who, in practice, rely on political appointments to build and manage legislative majorities and/or reward allies (Ames, 1995; Guedes, 1994; Raile, Pereira, \& Power, 2011). More recent municipal level research strengthens the argument that there is an important partisan connection between bureaucracy and parties: one third of municipal employees are party affiliated, a fact largely explained by the logic of patronage (Barbosa \& Ferreira, 2019).

In general, the media is responsible for spreading the idea that broad partisan patronage also exists in federal management. As if appointments respond to "physiological" criteria for assigning positions to "sponsored politicians" and "coreligionists" from parties that "organize" the state. Although references are made without mentioning formal party membership, this is often presupposed. Such a narrative and its corresponding terminological repertoires echo in the perception of citizens and solidify the image that points to the domain of party-political reason and disapproval of merit in federal bureaucracy, which the public largely views as system comprised of individuals lacking the competence needed to perform their administrative tasks.

Due to the lack of detailed or systematic data on party affiliations in bureaucracy, the specialized literature assumes that: a) appointing a party minister gives the party exclusive rights to choose names within high level ministerial bureaucracy; and b) that these choices are predominantly partisan. This is the case in the original analyzes on the relationship between government coalition and the president's legislative support, and usually this is related to the debate on party proportionality in the cabinet's power division (Amorim, 2019; Bertholini \& Pereira, 2017). ${ }^{1}$ In general, this analysis considers that the chain of command from the minister to his subordinates would flow through links connected by common party ties. ${ }^{2}$

\footnotetext{
${ }^{1}$ In the corridors of the Planalto and Congress these monopolistic rights of the minister's party are called "porteira fechada" (closed gate). ${ }^{2}$ This is implied, for example, in the passage underlined in the following remark: "In order to form a majority government post-election, presidents need to make at least three choices: (1) how many parties will form the coalition; (2) which parties and whether they have similar political and ideological preferences to the president; (3) and the amount of power and resources that will be shared between partners."(Pereira \& Bertholini, 2019, p. 313. emphasis added. Authors' translation). The analysis of the division of party power in the Executive is important in the literature on the functioning of Brazilian presidentialism because the equitable division has been considered an indispensable strategy for the President to maintain legislative support and expand the capacity to implement the government agenda (Amorim, 2000; Mauerberg, 2016; Pereira \& Bertholini, 2019; Raile et al., 2011).
} 
However, the division of power might not occur this way and understanding the real space that appointees with party affiliation occupy within the ruling ministerial bureaucracy - and variations by functional hierarchy, party label and mandates, for example - sheds light on this central process of governance: the designation of frameworks in decision-making bureaucracy. In doing so, this article contributes to the continued efforts that have been made to unravel the operational rules of Brazilian multiparty presidentialism and to identify important aspects pertaining to the contours of top-level federal management. This analysis provides additional elements to clarify the complexity of Brazilian presidentialism and its considerable party fragmentation (Calvo, Guarnieri, \& Limongi, 2015; Mainwaring, 1991), loose programmatic orientations for party labels, and rate of appointee turnover - ministers and bureaucrats - above desirable (Franz \& Codato, 2018; Lopez \& Silva, 2019).

In addition to its direct relevance for the study of political system, this article covers public management research - some published here in the Revista de Administração Pública - by discussing the connection between decision-making bureaucracy and partisan politics (Araujo \& Lameirão, 2010; Cavalcante \& Lotta, 2015; D’Araujo \& Petek, 2018; Pacheco, 2010). To that end, we describe and analyze systematic data on the partisan affiliations of appointees to public trust positions within Brazilian federal public administration in 6 different presidential terms, from 1999 to 2018. We also address a specific form of public sector politicization - partisanization. Previous analyzes of the politicization and partisanization of federal senior management either used shorter annual series or a lesser scope of management positions (D’Araujo \& Lameirão, 2010; D’Araujo \& Petek, 2018; Lopez, 2015; Lopez \& Praça, 2018, Praça, Freitas, \& Hoepers, 2011; Praça \& Lopez, 2019).

In the next section, we present concepts that guide data interpretation as well as general information on allocations and the number of trust positions within the Brazilian Federal Executive branch (called Cargos de Direção e Assessoramento Superior - DAS). In Section 3, we detail our methods of constructing the data. In section 4 , we look at the general rates of appointees' party affiliation. In section 5 , we present data on affiliations, by presidential parties and mandates. In section 6 , we discuss how the results could aid in a reassessment of certain assumed features of Brazilian presidentialism. And in the concluding section we summarize the argument and list future analyzes.

\section{APPOINTMENTS: POLITICIZATION, PARTISANIZATION AND PATRONAGE}

Competency and politics are neither dichotomous nor self-excluding terms, but evidence suggests the priority of political criteria in filling upper levels of administrative power, as the interface with the political sphere intensifies. Therefore, greater partisan control of the upper levels of decisionmaking bureaucracy is expected in relation to the other levels with discretionary appointments. This is a reasonable expectation. Greater proximity to politics increases bureaucratic responsiveness to the preferences of politicians, when compared to an autonomous bureaucratic framework (Page \& Wright, 1999). Furthermore, the autonomy of career bureaucracy may increase the costs of wanting to redirect state activities to new demands following the election of a new government (Peters \& Pierre, 2004).

On the other hand, the high degree of political and party influence in bureaucratic positions are harmful to the efficiency of public policies. Political-party rationale may diverge from technically superior decisions and prevent their implementation. Although there are few studies on the implications of politicizing upper bureaucracy for policy implementation, Lewis (2008) demonstrated that the high politicization of agencies increases their inefficiency because of 
instability caused by the increased turnover of individuals that do not make careers in government agencies and their limited management experience. ${ }^{3}$ Gailmard and Patty (2007) suggest that the combination of administrative powers that formulate public policies more independently of politicians and the temporary stability of positions encourages bureaucratic expertise and results in better agency performance. This would be an example of an administrative regime that the authors call "politicized competencies". Yesilkagit and Van Thiel (2008) argue that in the case of the Dutch administrative system, which operates under a parliamentary regime, the relationship between the formal autonomy of agencies and de facto autonomy from party influence in public policies can occur in the opposite direction; agencies that are more administratively independent may receive more political influence. The conclusion points to characteristics Hammond and Knott's (1996) emphasized in the North American case: bureaucratic autonomy is contingent on the strategies adopted by each of the three heads comprising the US federal administrative system - the Presidency, the House and the Senate.

In Brazil, we do not yet have the elements needed to analyze the implications of politicization on efficiency in the policy management cycle, but we can scale the party influence on different mandates and levels of administration. In this article, we present information about the partisanization of federal commissioned positions (DAS positions).

There can be various coinciding reasons when A nominates B for a DAS-5 position: simple friendship, the need to reciprocate electoral support to a political faction, ensuring that the individual selected will exercise the duties of the post with zeal, confidence in the administrative capabilities of $\mathrm{B}$, etc. Because the choice is discretionary, all motives, legitimate or otherwise, are worthy of consideration. Like Grindle (2012), we consider the discretionary nature of choice a sufficient condition for defining politicization, and trust positions are by nature politicized. In this way, we want to differentiate between politicization and partisanization. Partisanization is a specific form of politicizing without indication of whether the objectives are guided by desire to control public policy or are simply a way of handing out jobs (Weber, 2002). In addition, characterizing politicization as a discretionary choice, without normative connotations, and partisanization as the discretionary choice of individuals affiliated with parties, avoids preconceived notions - usually negative - between the attributes of appointees and their performance. ${ }^{4}$

Brazilian federal bureaucracy includes positions in administrative agencies, directly, indirectly (such as councils and foundations) and in the form of public companies. Public companies are excluded from this analysis because their positions possess their own designations and logic, and information, when made public, is not systematically accessible. Direct and indirect administration

\footnotetext{
${ }^{3}$ For Lewis (2008, p. 196) "[party] appointees get systematically lower PART scores than careerists and federal employees in politicized agencies are less likely to say their agencies are led and managed well or are good places to work. Previous bureau experience and longer tenure in management positions explain why careerist-run programs get higher grades. The advantages that appointees tend to have over careerist bureau chiefs, such as higher levels of education, private management experience, and work in other departments outside the bureau, are not significantly correlated to performance. Public affairs experience, however, does seem to help in one aspect of public management: translating political wishes into a clear program purpose and design." The Program Assessment Rating Tool (PART) was a management system that made it possible to score, measure and compare implementation of programs conducted by each US federal agency. The instrument was used under the G. W. Bush administration and discontinued during the B. Obama administration.

${ }^{4}$ The concept of politicization is often used to describe choices based on political criteria, without primary consideration for technical capacity. When this occurs, there is usually talk of political patronage, clientelism, etc. In this sense, it has always had a pejorative connotation, since it is difficult to identify the constellation of motives for choices; we do not enter this conceptual discussion and instead refer interested parties to the book by Kopecký, Mair, and Spirova (2012).
} 
- the ministries and associated agencies - is under the political control of the minister. Below the minister is the deputy minister - the so-called Executive Secretary - whose greatest assignment is to "play the ministerial machine" (Lopez \& Praça, 2015; Pereira, Batista, Praça, \& Lopez, 2017). Next come DAS positions - this article's object of analysis.

DAS positions are divided into six hierarchical levels, each of which has specific attributions and administrative power. The higher the level and power, the more frequent interaction with the political sphere (Graph 1). We designate 1 to 4 as middle-level and 5 and 6 as top-level. Because of the political and administrative significance, we focus mainly on top-level data, which represents about 1,200 positions, $6 \%$ of the total of the total DAS.

In 2005, after what the media called the "Mensalão Scandal", the federal government promulgated Decree n. 5,497 (2005), which required a minimum quota of 75\% of public servants appointed for DAS posts 1 to 3, 50\% for DAS-4 positions, but exempted levels 5 and 6 from quotas. Twelve years later, after administrative reform aimed to reduce the number of federal agencies, the Temer government promulgated Decree no. 9,021 (2017) and reduced by 50\% - no more than 75\% - the minimum quota for public servants in DAS posts 1 to 3. For levels 5 and 6, previously exempted, the minimum quota was set to $60 \%$ of appointees linked to the public sector, which formalized the average percentages already observed in PT administrations (Lopez, 2015). ${ }^{5}$

\section{GRAPH 1 AVERAGE PERCENTAGE OF DAS POSITIONS AND ATTRIBUTIONS, BY HIERARCHICAL LEVEL} (1999-2017)

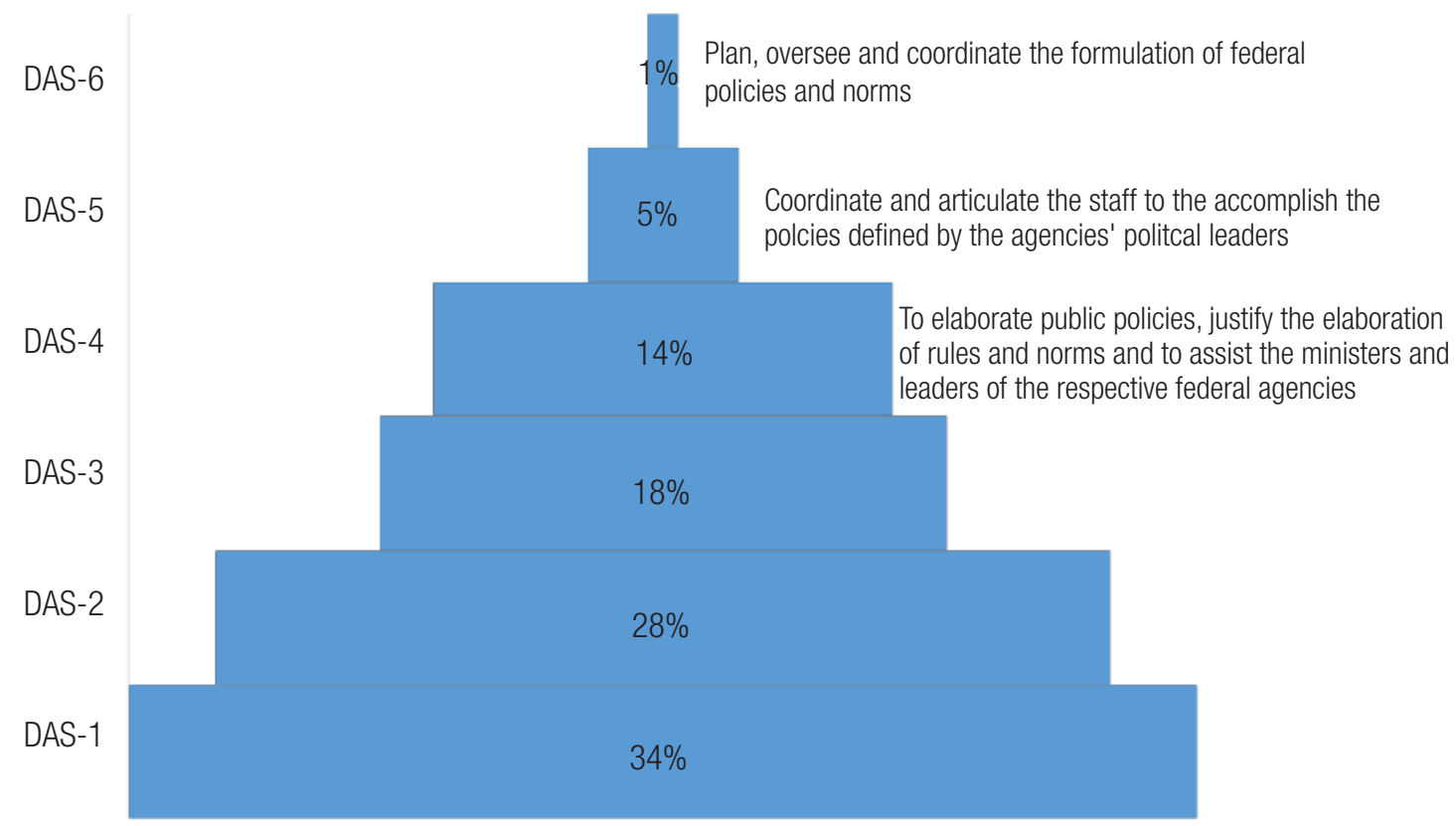

Source: Elaborated by the authors..

${ }^{5}$ We refer to the power to indicate as well. It is known that there is, formally, the definition of who officially appoints, but the official act veils this relevant point: the negotiations that take place behind the scenes, where who, in fact, secures the nomination of the nominee is defined. 
Despite variations throughout the period under review, the rules of appointment more or less observe the following general criteria: ministers officially select and nominate appointments for DAS posts at levels 1 to 4, and at the upper echelon (levels 5 and 6), formal power is held by the Civil House or the President of the Republic. But there have been changes over time. For example, during the first year of the Lula administration, in 2003, the Minister of the Casa Civil was granted the right to carry out the official appointment of all DAS positions (levels 1 to 6). The Casa Civil ${ }^{6}$ could delegate this authority to the ministers, at levels 1 to 4 , but would have "the right to intervene in appointments in case of administrative necessity" (Lameirão, 2015, pp. 189-190, emphasis from the original work). ${ }^{7}$

Knowing to what degree appointments are actually the choice of the minister, the minister's parties, other members of upper bureaucracy, or the imposition of the Casa Civil or the President would require more detailed archaeological work behind the scenes of politics, but may be partially illuminated by the data in this article.

Between 1999 and 2014 there was a large increase in the number of DAS positions, followed by a reduction after this period, due to the changes mentioned (see Graph 2). The cumulative increase in total DAS positions from 1999 to 2014 was 34.6\%, of the series average (Graph 2, Table 1), which corresponds to the increase in the number of federal servants during the same period (Graph 2, Table 2). After 2015, there was a reduction of $28.4 \%$ of the positions. Table 3 of Graph 2 shows there is a minor variation in the proportion of DAS over total active federal servants; this ratio never exceeded $4 \%$. That is, the increase in the commissioned positions was driven by the expansion of the workforce in the federal Executive.

Administrative systems almost always politicize top management at some level (Kopecký, Mair, \& Spirova, 2012; Kopecký et al., 2016; Peters, 1999; Peters \& Pierre, 2004). National variations largely depend on the course of national development and correspond to different administrative cultures (Grindle, 2012; Mikkelsen, 2018; Painter \& Peters, 2011; Peters, 1999). ${ }^{8}$ Each culture responds uniquely to the tension that arise between pursuing efficiency, which stems from a group of top-level permanent bureaucrats and specialists, and the need for responsiveness to changes in partisan political command of the state or public agencies (Page \& Wright, 1999).

In the Brazilian federal administration, the border between the direct influence of politics, the parties, and the parliamentarians is blurred and shifting, creating an ambiguous space where politics and administration, the ideological-partisan preferences of the administrator, and the technical capacity to execute decisions inherent to positions becomes indistinguishable. DAS turnover is a way of studying the connections between politics and public administration. The federal administration has an annual turnover rate of approximately $30 \%$, though there are important variations in the years that follow a presidential election (Lopez, M. Bugarin, \& K. Bugarin, 2015). The turnover drops after the second year of government and reaches a new peak at the beginning of each term. Party changes in ministry control increase ministry turnover by approximately $20 \%$; after factional changes - when the minister changes, but not the party in charge of the ministry - turnover increases by $11 \%$ (Lopez et al., 2015). In top-level DAS positions, the high instability of discretionary appointees is similarly demonstrated by a median survival time of 25 and 22 months, respectively (Lopez \& Silva, 2019).

\footnotetext{
${ }^{6}$ Equivalent to the Executive Office of the President, in USA.

7 The institutional evolution of Fernando Henrique Cardoso's (FHC) nomination rights up to the Dilma Rousseff government was explored in detail by Lameirão (2011a, 2013, 2015) and D’Araújo and Lameirão (2011).

${ }^{8}$ Painter and Peters (2011) identify 9 different administrative traditions, which help to understand persistent - though evolving - legacies of ways for organizing state agencies and dividing their administrative power.
} 


\section{GRAPH 2 EVOLUTION OF THE NUMBER OF DAS POSITIONS (1999-2018)}

Total of DAS appointees, by year (1999-2018)

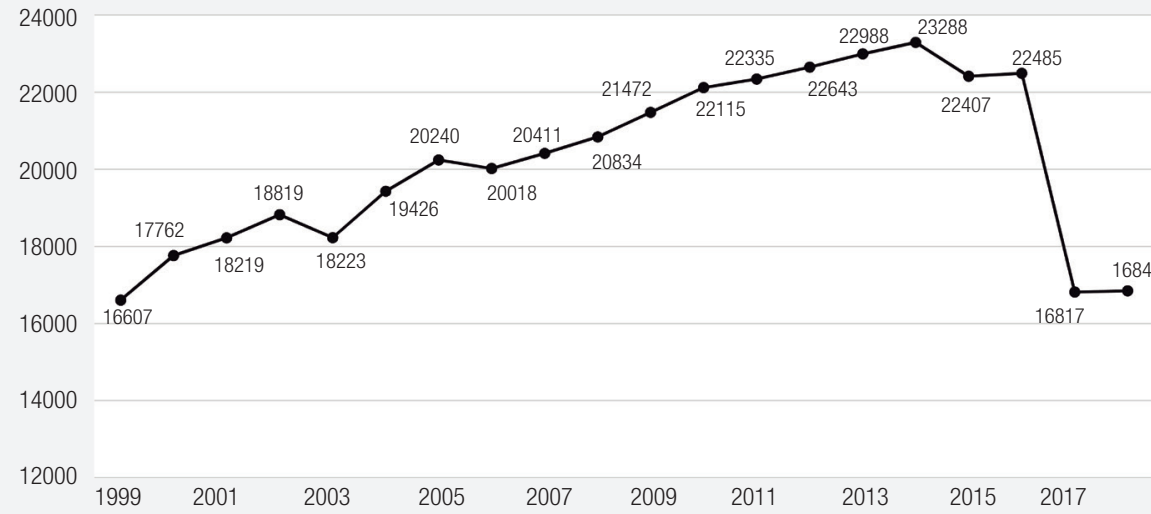

Total of federal civil servants in activity, by year (1999-2018)

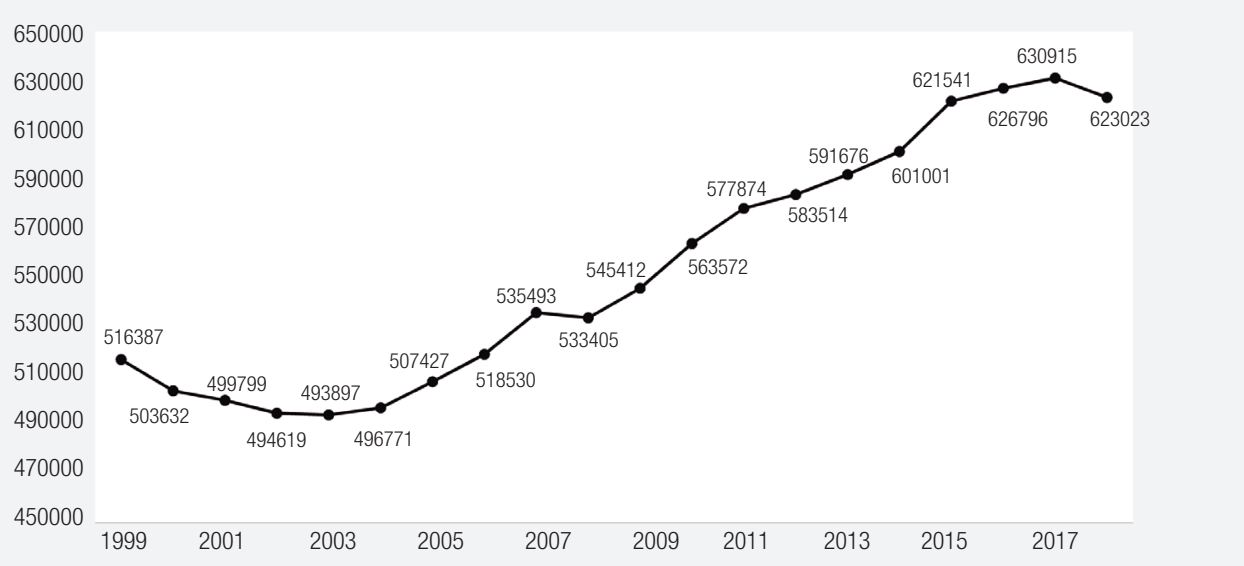

Percentage of DAS appointees in the total of federal civil service (1999-2018)

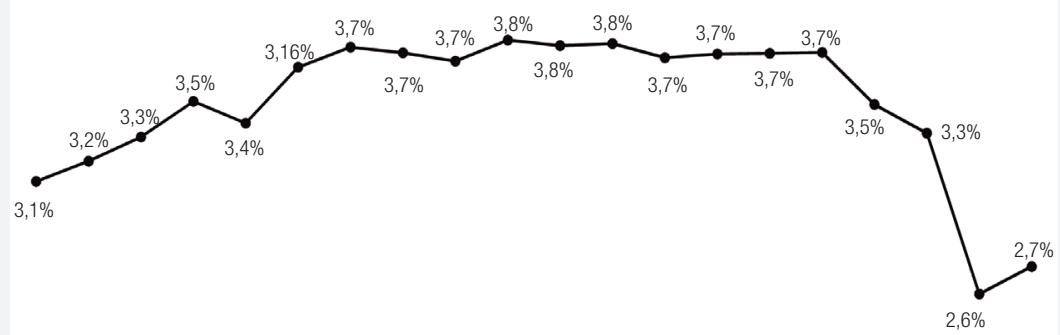

19992000200120022003200420052006200720082009201020112012201320142015201620172018

Source: Elaborated by the authors. 
This turnover and survival metric for positions shows that political influence over bureaucracy is greater at the highest levels of management (Lopez et al., 2015; Lopez \& Praça, 2015). In addition to the aforementioned administrative influence, it contributes to the remuneration and prestige associated with posts at higher levels, which make these posts more inviting to people outside the public sector.

An additional step towards understanding the relationship between party politics and top administration is provided by the data on affiliations. To what extent do governments recruit affiliates for DAS posts? Does this recruitment vary by level or between governments? Which parties recruit the most affiliates? Is recruitment limited to coalition parties?

In the following sections, we analyze data construction and the answers to these questions.

\section{DATA AND METHODS}

The methods adopted here are descriptive (Gerring, 2012) and aim to present some indicators and tendencies on partisanization in bureaucracy. Data were extracted from the Federal Government's Personnel Administration System (SIAPE) and the nationwide list of political party affiliates available on the website of the Superior Electoral Court (TSE, n.d.).

From SIAPE, we use the voter registration number of the federal civil servants, available since 2014. ${ }^{9}$ From the TSE (n.d.) records, we collected data related to members of political parties, the date, and the party label of membership, as well as voter ID card number. Thus, as of 2014, there has been a secure single indicator for the information on civil servants appointed to DAS positions and party affiliation: the voter ID card number. Between 2014 and 2018, this indicator made it possible to consistently address the problem of individuals with the same names. ${ }^{10}$ For previous years, we combined SIAPE databases with affiliation data containing the names of civil servants and affiliates. In both periods, we obtained a similar affiliation rate, around $12 \%$ of DAS employees.

The question of affiliates with the same name (between 1999 to 2013) was resolved by adopting the following procedure: we used 2014 to 2018 voter registration data from the population of federal servants to identify whether people with the same names in the TSE database were federal servants. For the remaining residual cases, we checked whether the subnational state of affiliation was the same as the subnational state where the federal agency was located, in which case we assumed that it was a person linked to the federal public sector. The criteria cannot be applied to homonymously named servants without links to the public sector. But since these cases represent only a tiny fraction of DAS members, the changes are merely residual. The period from 2014 to 2018 served as an external validation for our decision not to indiscriminately include all homonymously named public servants, and thus we avoided incorrectly inflating the percentage of affiliates. Using this standard, we constructed a database that coincides with the first year data on servants in the SIAPE system was made available (1999-2018), and this allowed for a more comprehensive analyzes. For all cases, we adopted the standard control to verify whether the party affiliation preceded the date of appointment. In the TSE (n.d.) records we excluded cases listed as "canceled", "disaffiliated", and "sub judice"; 77\% were found to be in a regular situation, and the others were "canceled" (21\%), "disaffiliated" (2\%), or other $(0.4 \%)$.

\footnotetext{
${ }^{9}$ This information is not in public databases and is restricted to the then Ministry of Planning Development and Management. The data were used as part of collaborative projects between MPDG and IPEA. IPEA is administratively linked to the MPDG.

${ }^{10}$ The topic of individuals with the same names was discussed by Praça et al. (2011) and Barbosa and Ferreira (2019).
} 


\section{AFFILIATIONS AND POSITIONS OF TRUST - SENIOR DIRECTORATE AND ADVISORY}

This section presents longitudinal information and describes broader arguments formulated in Lopez and Praça (2018). ${ }^{11}$ In the population of 421,000 DAS positions, from 1999 to 2018, party-affiliated members constituted $13 \%$ of the total, higher than the $8 \%$ observed in the estimated Brazilian population, which in 2015 had 16.5 million members of political parties. This percentage suggests that it is not primarily through formal affiliation that the party ties of appointees to federal trust positions exist, if they do so at all. But the percentage varies significantly by hierarchical level and ranges from $12 \%$ and $11 \%$, at the lowest levels (DAS 1 to 3), to $28 \%$ at the highest level (DAS-6) (Graph 3). ${ }^{12}$

GRAPH 3 PERCENTAGE OF PARTY AFFILIATES, BY HIERARCHICAL LEVEL OF DAS POSITION (1999-2018)

DAS-1

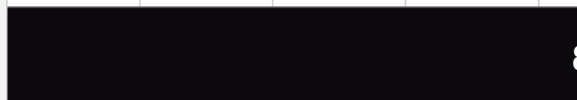

\section{8}

DAS-2

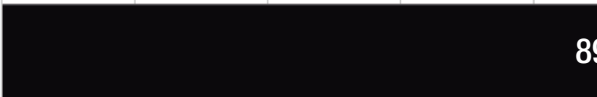

89

DAS-3

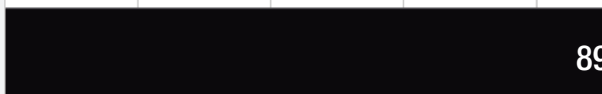

89

DAS-4

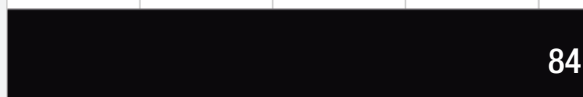

84

DAS-5

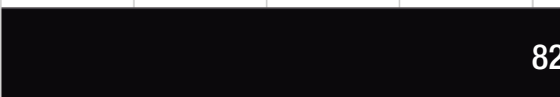

82

DAS-6

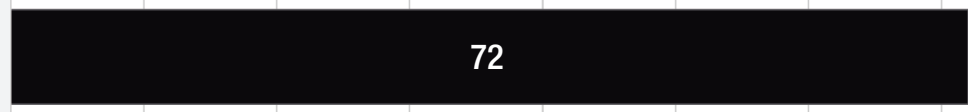

28

- \% non-affiliated - \% affiliated

Source: Elaborated by the authors.

\footnotetext{
${ }^{11}$ An analysis of differences observed between public policy areas or ministries will be analyzed in future text.

${ }^{12}$ The percentages are close to those reported by Barberia and Praça (n.d.), which indicates an overall membership rate of $12 \%$ in DAS position occupants during 2010.
} 
The affiliation rate of appointees that are career civil servants with no ties to the public sector is significantly higher, especially at levels 5 and 6 (Graph 4). In DAS-5, servants with ties to the public sector and party affiliations corresponded to $9 \%$, a percentage that rises to $27 \%$ (at the same hierarchical level) among those with no ties. Among DAS-6 positions, the affiliation rates are $12 \%$ among servants and $35 \%$ among appointees without ties to the public sector. These percentages have notably diverged since 2003, the first of 13 years in which the Workers Party (PT) controlled the presidency. The trend was maintained during the Temer government (Graph 4).

A number of factors might explain the differences in the degrees of affiliation among career civil servants with ties to the public sector and those without ties. The most important point to take away is that top-level posts enjoy broader passage through the political sphere and are more coveted because of their greater control over public policies and their ability to influence major decisions. ${ }^{13}$ Generally, Graph 4 reveals that management is less partisanized when positions are filled by career civil servants. ${ }^{14}$

It should be noted, that growth in the proportion of affiliates from PT presidencies was also accompanied by an increase in the percentage of career civil servants in top-level positions (Lopez, 2015). In other words, there was a rise in the percentage of party affiliates, especially those from outside the public sector, but professionalization in DAS positions also increased.

The third feature worth noting - represented by the middle line in Figure 4 - is that the sources of politicization lie outside the circle of formally affiliated individuals. In the next section, we discuss partisan links through mandates and party labels.

\footnotetext{
${ }^{13}$ Higher-level positions are also a higher award for servants or co-religionists: they pay more, have more power, and have more prestige. ${ }^{14}$ The differences between civil servants and non-civil servants and the fact that most top-level appointees have no formal party ties does not necessarily exempt civil servants from party-based motives or from performing political activities. This possibility gives political leaders opportunities to place servants more in tune with their preferences into public careers. Here, however, we would need to enter into a further discussion on the relationship between careers, affiliations and bureaucratic neutrality, which is not appropriate at this time.
} 
Percentege of DAS-5 and DAS-6 affiliated to parties, by type of link with public sector (1999-2018)

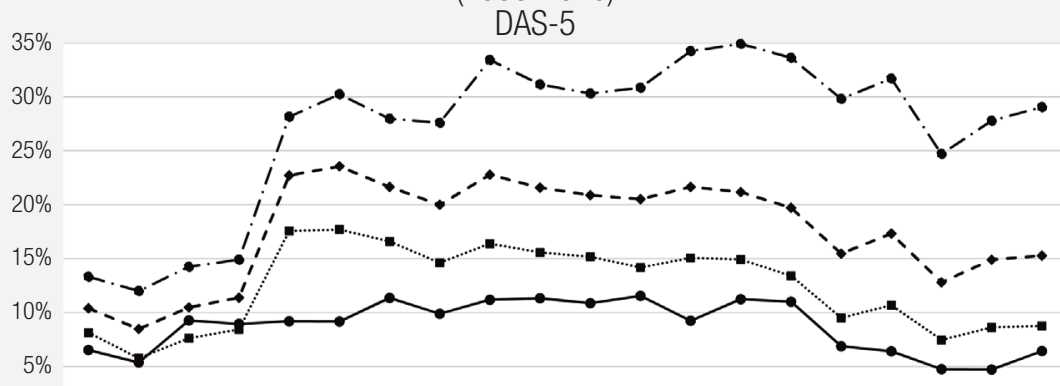

0\% 19992000200120022003200420052006200720082009201020112012201320142015201620172018

... DAS-5 from career civil service and affiliated _ _ all DAS-5 appointees affiliated

$\rightarrow$ - DAS-5 from private or non-state sector and affiliated $\rightarrow$ - DAS-5 from federal careers and affiliated

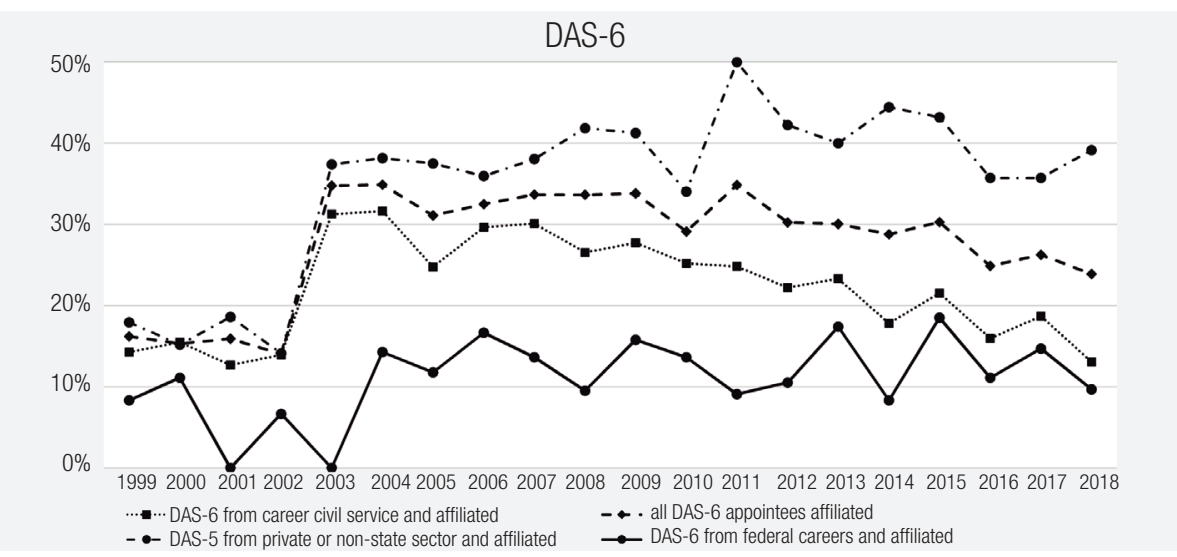

Source: Elaborated by the authors.

\section{AFFILIATIONS, PARTY LABELS AND MANDATES}

Affiliation rates vary between mandates. At all levels - from 1 to 6 - the increase in the percentage of affiliates starting with the PT administration is visible. In DAS 5 and 6, the proportion of members doubled when comparing the average of the first Lula term with the second term average of Fernando Henrique Cardoso (FHC). ${ }^{15}$

Among the Lula and Dilma administrations, there was no significant difference in membership rates (Table 1), although there was a marked increase among appointees from outside the public sector, with peaks in 2003 and 2011 (Graph 4, previous section).

\footnotetext{
${ }^{15}$ Nogueira and Cardoso (2011) point to the relevant presence of consultants hired through international agencies in the FHC government. Often, these consultants perform the same tasks and substitute senior management DAS functions. Caution is therefore needed in assuming that the relative value of DAS in all positions of power in the ministries - or some of them - is stable, also because there was a salary recomposition of these positions from 2003, already during the Lula administration.
} 


\begin{tabular}{|c|c|c|c|c|c|c|c|c|c|c|c|c|}
\hline Mandate & $\begin{array}{l}\text { Total } \\
\text { DAS-1 }\end{array}$ & $\begin{array}{c}\% \\
\text { DAS-1 } \\
\text { affiliated }\end{array}$ & $\begin{array}{l}\text { Total } \\
\text { DAS-2 }\end{array}$ & $\begin{array}{c}\% \\
\text { DAS-2 } \\
\text { affiliated }\end{array}$ & $\begin{array}{l}\text { Total } \\
\text { DAS-3 }\end{array}$ & $\begin{array}{c}\% \\
\text { DAS-3 } \\
\text { affiliated }\end{array}$ & $\begin{array}{l}\text { Total } \\
\text { DAS-4 }\end{array}$ & $\begin{array}{c}\% \\
\text { DAS-4 } \\
\text { affiliated }\end{array}$ & $\begin{array}{l}\text { Total } \\
\text { DAS-5 }\end{array}$ & $\begin{array}{c}\% \\
\text { DAS-5 } \\
\text { affiliated }\end{array}$ & $\begin{array}{c}\text { Total } \\
\text { DAS-6 }\end{array}$ & $\begin{array}{c}\% \\
\text { DAS-6 } \\
\text { affiliated }\end{array}$ \\
\hline FHC \| & 11170 & $9 \%$ & 8662 & $8 \%$ & 4029 & $8 \%$ & 2758 & $10 \%$ & 946 & $10 \%$ & 205 & $15 \%$ \\
\hline Lula I & 11424 & $12 \%$ & 8207 & $11 \%$ & 4859 & $12 \%$ & 3805 & $17 \%$ & 1192 & $22 \%$ & 256 & $33 \%$ \\
\hline Lula II & 11464 & $13 \%$ & 9002 & $12 \%$ & 5604 & $13 \%$ & 4318 & $17 \%$ & 1251 & $21 \%$ & 243 & $33 \%$ \\
\hline Dilma I & 11909 & $14 \%$ & 9653 & $13 \%$ & 6157 & $13 \%$ & 4979 & $18 \%$ & 1421 & $19 \%$ & 305 & $31 \%$ \\
\hline Dilmall & 7172 & $11 \%$ & 6123 & $9 \%$ & 4182 & $9 \%$ & 3539 & $16 \%$ & 1089 & $17 \%$ & 215 & $30 \%$ \\
\hline Temer & 9530 & $12 \%$ & 8159 & $11 \%$ & 4908 & $10 \%$ & 4363 & $15 \%$ & 1531 & $14 \%$ & 300 & $25 \%$ \\
\hline
\end{tabular}

Source: Elaborated by the authors.

Note: The data refer to the occupants of DAS posts for the month of December, in each year. Consequently, for the Dilma II government, only the year 2015 was considered. The year 2016 was attributed to the Temer government, which assumed the Presidency of the Republic in May and was officially sworn into office in August 2016. Although in December 2016, the transition of senior management names could technically still have been underway, in reality it had already been mostly completed.

The strategy of sharing power within political bureaucracy differed between the PSDB, PT, and PMDB presidencies. In the FHC II government, affiliation rates were primarily distributed among coalition parties. ${ }^{16}$ The PSDB and PMDB held $31 \%$ and $25 \%$ of DAS affiliates. But the Democratas (formerly the PFL) and the PP (formerly the PPB) had 10\% and 6\% respectively of top-level members - percentages lower than those of the PT, which at the time, was the opposition.

In the Lula and Dilma governments, affiliates in top-level bureaucracy were concentrated in the PT. In DAS 5 and 6 positions, among the party appointees, percentages varied between 39\% of PT affiliates, in the second term of Lula, and reached 53\% in Dilma's second term. In addition to discovering that the PT concentrated political power in the division of ministerial positions (Bertholini \& Pereira, 2017, Praça et al., 2011), there is also a concentration in upper level bureaucratic posts. ${ }^{17}$

\footnotetext{
${ }^{16}$ PMDB, PSDB, Democratas and the PP - at the time the PPB (Nexo, 2018) - were part of the cabinet. The Democratas (then the PFL) left office in March 2002 (Almeida, 2018). The lower PFL average is expected to reflect this year outside the fourth year of FHC's second term, since DAS data refer to December of each year. We thank Ipea's Acir Almeida researcher for making available the database on coalition parties and cabinet parties.

${ }^{17}$ The cabinet - whose number of parties is usually smaller than the number of parties in the parliamentary coalition - of Lula's first term was composed of the following parties: the PT, PL, PC do B, PSB, PTB, PDT, PPS and the PV. Still in 2003, the PDT left the cabinet. The PPS then joined the cabinet. In early 2004, the PMDB joined the cabinet. In the first year of the second term, Lula's office was composed of the PT-PR-PC do B-PSB-PTB-PMDB-PP-PDT-PV. In 2010, the PV left the cabinet. The first year cabinet of Dilma's government in 2011 consisted of the following parties: the PT, PR, PC do B, PSB, PMDB, PP and PDT. In 2012, the PRB joined the cabinet and the PSB left. In the first year of Dilma's second term, 2015, the cabinet was composed of the following parties: the PT, PR, PC do B, PMDB, PP, PDT, PRB, PROS, PSD and PTB. The Temer government set up its cabinet with the following parties: the PMDB, PSDB, DEM, PP, PR, PSD, PTB, PRB, PSB and the PPS (Almeida, 2018).
} 
This concentration has at times been criticized by coalition partners. ${ }^{18}$ In the Temer government, deconcentration begins to take place again, even though the PMDB has the highest percentage of affiliates (26\%, according to Table 2$)$.

TABLE 2 NUMBER AND PERCENTAGE OF PARTY AFFILIATED APPOINTEES, EXCLUDING NON-AFFILIATED - FOR DAS 5 AND 6 POSTS, BY PRESIDENTIAL TERM (1999-2018)

\begin{tabular}{|c|c|c|c|c|c|c|c|c|}
\hline \multicolumn{3}{|c|}{ FHC II } & \multicolumn{3}{|c|}{ Lula I } & \multicolumn{3}{|c|}{ Lula II } \\
\hline Partie & $\mathrm{N}$ affiliated & $\%$ affiliated & Partie & $\mathrm{N}$ affiliated & $\%$ affiliated & Partie & $N$ affiliated & $\%$ affiliated \\
\hline PSDB & 51 & $31 \%$ & PT & 275 & $65 \%$ & PT & 236 & $57 \%$ \\
\hline MDB & 41 & $25 \%$ & MDB & 34 & $8 \%$ & MDB & 44 & $11 \%$ \\
\hline PT & 22 & $13 \%$ & PSDB & 24 & $6 \%$ & PSDB & 28 & $7 \%$ \\
\hline DEM & 16 & $10 \%$ & PC do B & 15 & $4 \%$ & PDT & 18 & $4 \%$ \\
\hline PDT & 11 & $7 \%$ & PSB & 14 & $3 \%$ & $P C$ do $B$ & 15 & $4 \%$ \\
\hline PP & 10 & $6 \%$ & PPS & 12 & $3 \%$ & PP & 13 & $3 \%$ \\
\hline PTB & 4 & $2 \%$ & PDT & 10 & $2 \%$ & PSB & 13 & $3 \%$ \\
\hline PPS & 3 & $2 \%$ & PTB & 9 & $2 \%$ & DEM & 10 & $2 \%$ \\
\hline PR & 2 & $1 \%$ & PP & 8 & $2 \%$ & PTB & 10 & $2 \%$ \\
\hline PSB & 2 & $1 \%$ & DEM & 6 & $1 \%$ & PPS & 7 & $2 \%$ \\
\hline Others & 2 & $1 \%$ & Others & 5 & $1 \%$ & Others & 6 & $1 \%$ \\
\hline \multicolumn{3}{|c|}{ Dilma I } & \multicolumn{3}{|c|}{ Dilma II } & \multicolumn{3}{|c|}{ Temer } \\
\hline Partie & $\mathrm{N}$ affiliated & $\%$ affiliated & Partie & $\mathrm{N}$ affiliated & $\%$ affiliated & Partie & $\mathrm{N}$ affiliated & $\%$ affiliated \\
\hline PT & 248 & $53 \%$ & PT & 142 & $56 \%$ & MDB & 89 & $26 \%$ \\
\hline MDB & 55 & $12 \%$ & MDB & 35 & $14 \%$ & PSDB & 42 & $12 \%$ \\
\hline PSDB & 23 & $5 \%$ & $P C$ do B & 13 & $5 \%$ & PT & 25 & $7 \%$ \\
\hline PDT & 22 & $5 \%$ & PDT & 12 & $5 \%$ & PSB & 20 & $6 \%$ \\
\hline PSB & 21 & $4 \%$ & PSDB & 7 & $3 \%$ & PP & 19 & $5 \%$ \\
\hline PC do B & 20 & $4 \%$ & PP & 6 & $2 \%$ & PPS & 19 & $5 \%$ \\
\hline DEM & 18 & $4 \%$ & PRB & 6 & $2 \%$ & DEM & 18 & $5 \%$ \\
\hline PP & 16 & $3 \%$ & PSB & 6 & $2 \%$ & PDT & 13 & $4 \%$ \\
\hline PTB & 10 & $2 \%$ & DEM & 5 & $2 \%$ & PV & 13 & $4 \%$ \\
\hline PPS & 5 & $1 \%$ & PSD & 5 & $2 \%$ & PRB & 12 & $3 \%$ \\
\hline Others & 5 & $1 \%$ & Others & 3 & $1 \%$ & Others & 12 & $3 \%$ \\
\hline
\end{tabular}

Source: Elaborated by the authors.

\footnotetext{
${ }^{18}$ In our view, however, there could be diverse implications of this concentration. On the one hand, it generates political dissatisfaction among the allies; on the other hand, it may be a way for the president to improve coordination in the sectoral policy cycle amid party and factional fragmentation.
} 
The majority of affiliated appointees belonged to parties situated as much in DAS 1 to 4 position as from DAS 5 to 6 - except in the FHC II government, when the opposition occupied more posts in the middle tier (Graph 5). Even during the PT mandates, when there was a greater concentration of party label affiliates, access to affiliates from opposition parties during the period considered was higher than $30 \%$-- for DAS 1 to 4 positions -- except during Lula II (26\%). At the top-level, opposition members controlled, on average, $15 \%$ of posts in PT mandates, as well as $36 \%$ and $28 \%$ respectively during the terms of FHC II and Temer (Graph 5).

If we consider that the majority of the appointees are not affiliated, it indicates that a small fraction of the high-ranking positions are occupied by members of opposition parties, with totals always below $10 \%$ (Figure 5A).

In general, the lower the hierarchical level, the greater the diversity and proportion of party affiliates outside the cabinet (Graph 5). Diversity is restricted to coalition parties, at hierarchical levels or to appointees without affiliation. Greater diversity of parties in middle rankings, coupled with the fact that the affiliated appointees are in the minority, suggest that partisan controls on access to bureaucratic power are not rigid, although they steer a significant portion of the choices.

The fact that affiliated civil servants from parties outside the cabinet - including the opposition assume or remain in office is partly explained by the experience servants have in performing specific functions. The microdata reveals that some appointees affiliated to the same party are able to shift unscathed from administrative changes during the presidential mandates of different parties in the House plenary. NON-COALITION PARTIES, IN TOTAL MEMBERSHIP, BY HIERARCHICAL GROUPS (1999-2018)

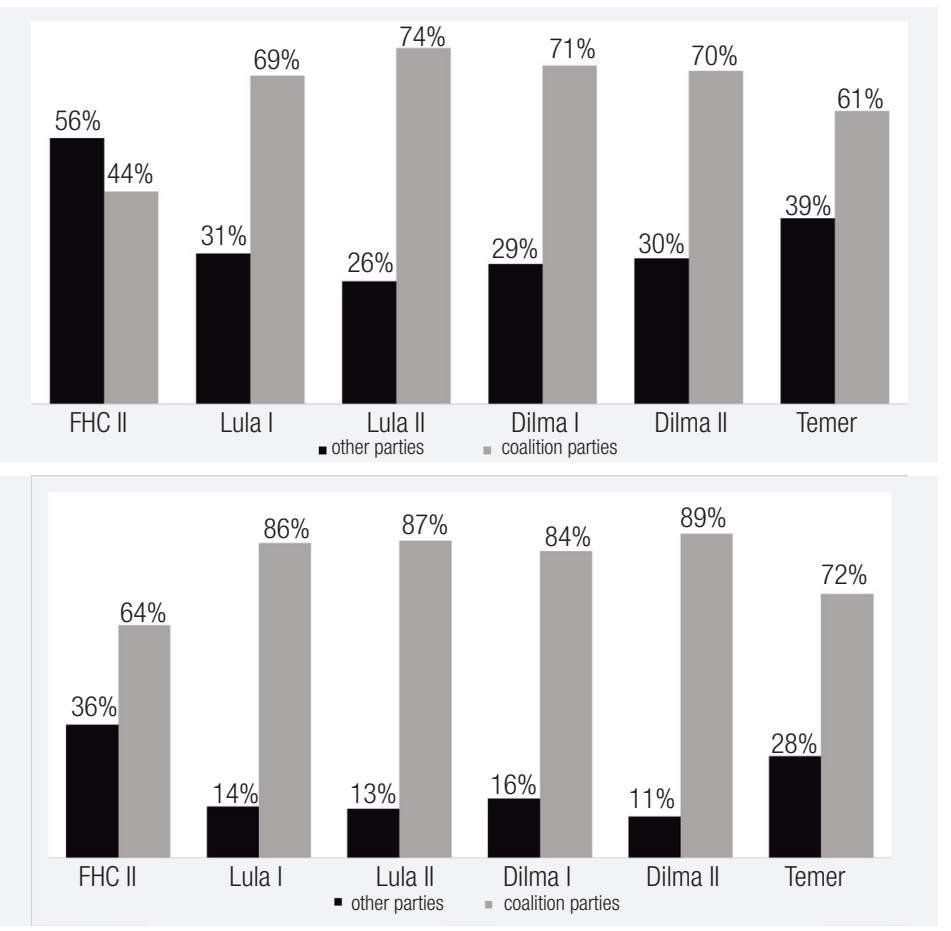

Source: Elaborated by the authors. 


\section{GRAPH 5A PROPORTION OF NON-AFFILIATED, AFFILIATED TO PARTIES OF THE SITUATION AND OPPOSITION IN THE POSITIONS OF DAS, BY HIERARCHICAL GROUPS (1999-2018)}
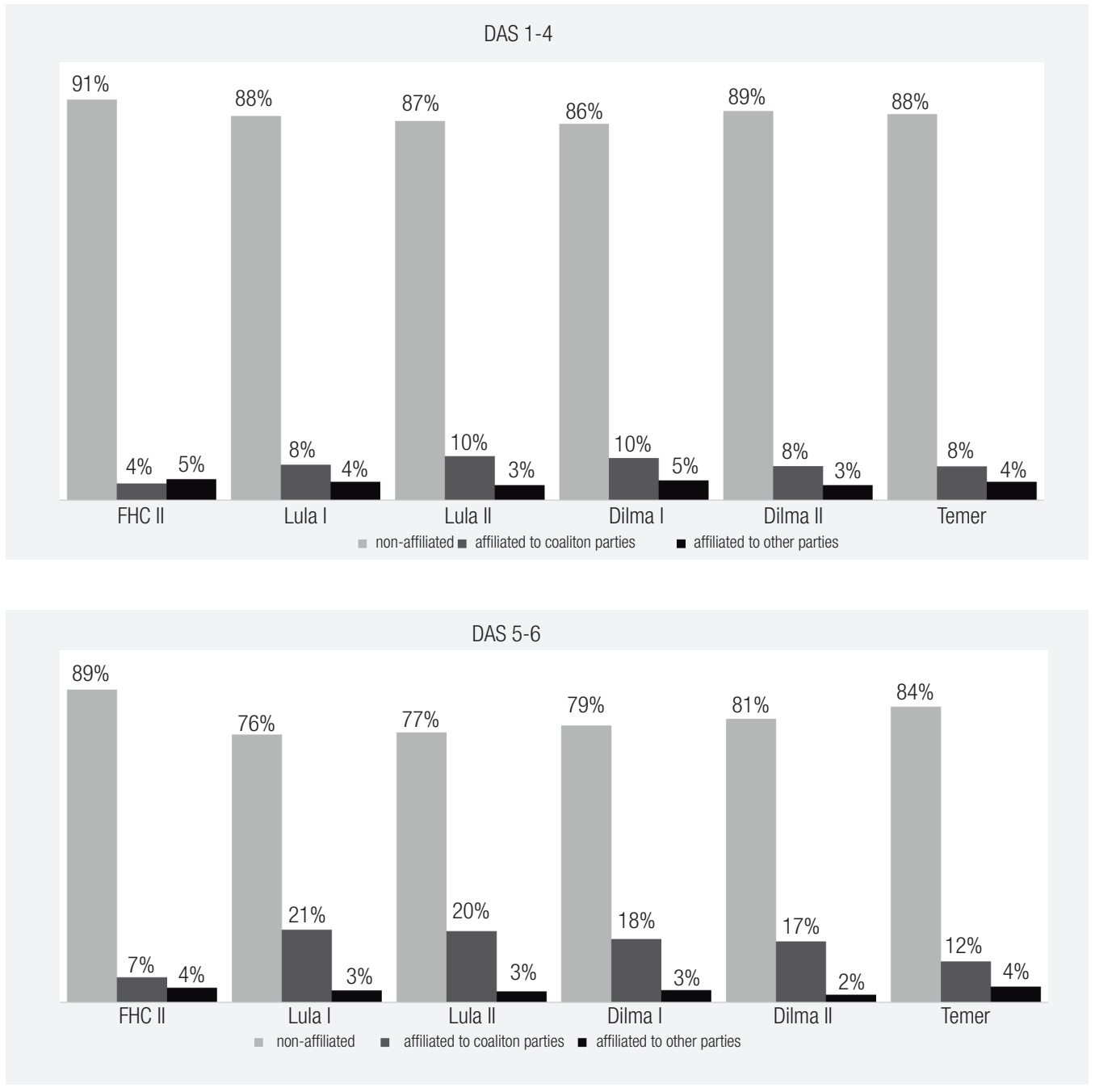

Source: Elaborated by the authors.

The diversity of party labels in middle and upper echelons - and increases in the number of party labels among middle-tier members - is similarly expressed by the fact that, in the span of 19 years, the average number of party labels with affiliates is 28 , in the middle echelon, and 18 , in the upper echelon. In the middle echelon, the absolute number almost always oscillated above 20 and included parties without legislative representation; at the highest level, the number of party labels increased from 12 in 1999 to 28 in 2018. This trend also reflects the fragmentation of party representation from 17 to 28 party labels between 1999 and 2018 (Graph 6). 


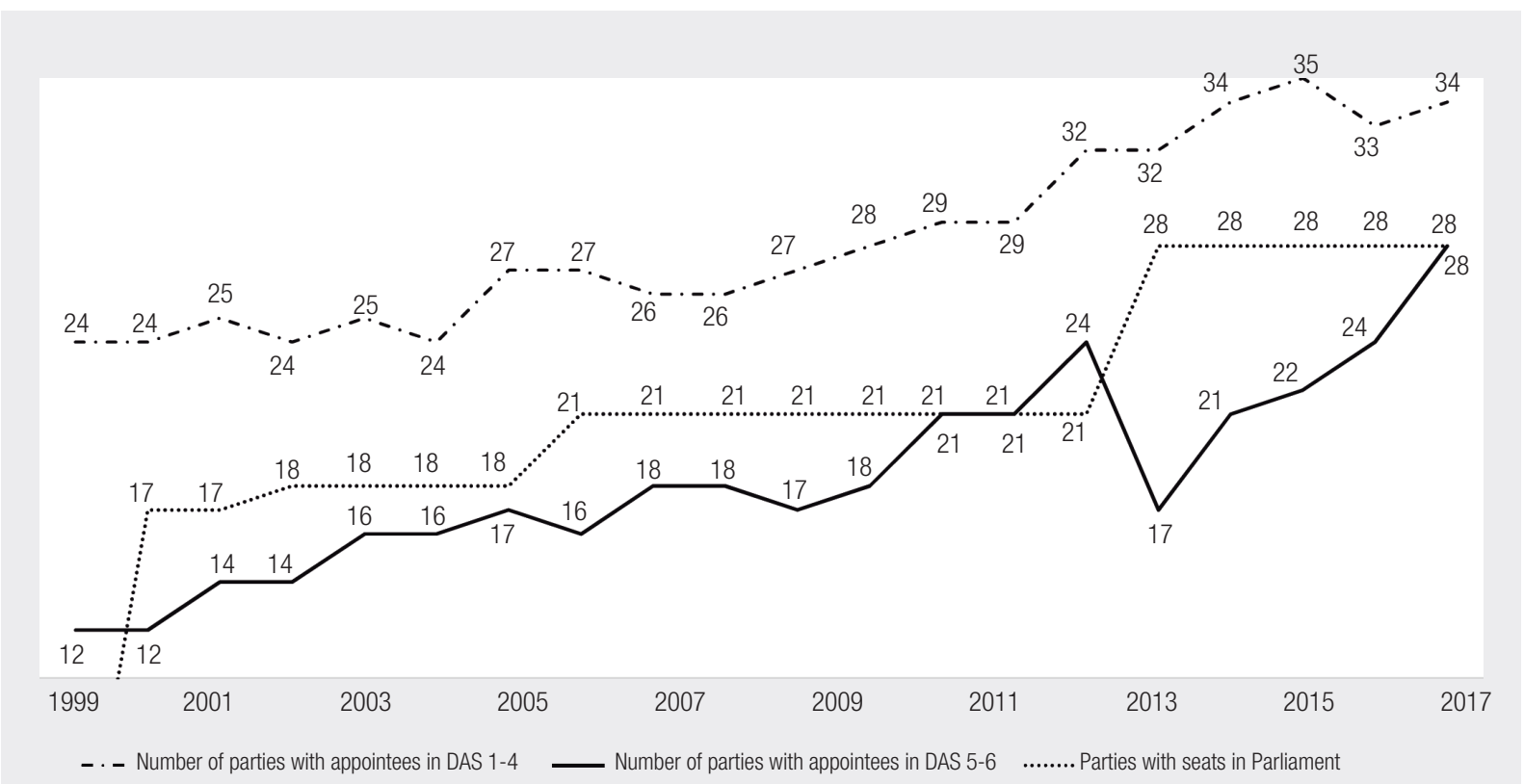

Source: Elaborated by the authors.

The data do not allow us to evaluate if there are alternative forms of politicization in the political bureaucracy. But this is a reasonable expectation for three reasons. First, the fragile societal and programmatic identity of parties weakens the selection requirements conditioned by the sign of affiliation, but motivated by affinities in preferences. Second, among the bureaucracy that moves along the "Ministries Esplanade", many of the fiercest supporters of partisan programs do not appear on the affiliation rosters, although informal adherence to them is apparent. Third, alternative sources of politicization that originate in nonpartisan political networks are important, and flow outside of parties, as documented in Lopez and Praça (2015). ${ }^{20}$

Finally, the small percentage of affiliates does not mean that common preferences among the selected, or affinities between bureaucrats and politicians, are irrelevant. On the contrary, the affinity of preferences is presumably relevant and denotes the most genuine sense of politicizing bureaucracy, but does not depend on the formal act of affiliation.

\footnotetext{
${ }^{19}$ The number of party affiliates in DAS 1 to 4 and DAS 5-6 ranks outnumbers the number of parties with parliamentary representation, as some commissioners are affiliated with party labels without parliamentary representation - as is the case with parties like the PCB and the PSTU.

${ }^{20}$ For example, the Ministry of Justice, at one point, featured among its high-ranking cadres individuals chosen from professional circles formed at Largo de São Francisco, in São Paulo, not by their partisan origin. Loureiro, Abrucio, and Rosa (1998) and Codato, Dantas, Aguiar, and Calabrez (2018) provide additional examples for the economic sector.
} 


\section{PARTY AFFILIATION RATES AND EXECUTIVE BRANCH STUDIES}

The data presented in this work suggest that it is necessary to also consider the division of power within the ruling bureaucracy, apart from the Ministers, to assess the real influence of the parties on the Executive's agenda.

An additional step needed would be an analysis how affiliations have varied between policy areas and ministries. The response to inter- and intra-ministerial divisions is important for indicating how homogeneous partisan presence is in state agencies.

Some additional aspects should be considered in studies aiming to understand the profile of those selected for governing federal bureaucracy. First, career appointments are a relevant and dominant motivation for the selection of positions, even if the proportion decreases at higher levels. Second, the selection of appointees without party ties, but with similar ideologies, is decisive for choosing cadres. This point can be seen in the case studies of federal agencies, such as the Central Bank of Brazil (Olivieri, 2007), and the Ministry of Finance (Codato et al., 2018; Loureiro et al., 1998). In general, the reading of these cases indicates that party presence in the governing bureaucracy is greatly conditioned by the institutional history of federal agencies, the nature of the policies, and by extraparty networks of affiliation, such as academic ties. These differing grammars (Nunes, 1997) define a more multifaceted scenario than the logic of party affiliations can capture alone.

The data also point to a greater representation of the PT in their respective presidential mandates. A more detailed study is needed to evaluate whether the difference was due to a greater supply of partisan cadres from the PT - vis-à-vis the other parties - or greater demand for power by its coreligionists - which is amplified by the diversity of party factions.

Finally, it is worth considering the hierarchy of effective power in posts. By this term we refer to the resources of power intrinsic to the nature of the function, not to the hierarchy of the position. Being the minister's chief of staff is quite different in nature than being a superintendent at a regional agency. Although they are in equivalent hierarchical positions, the second would be the object of greater partisan political interest. Likewise, those responsible for concluding or approving large contracts have positions that are more decisive than other tasks common in mid hierarchical levels. Passing a "fine comb" on the nature of activities between levels and differentiating the nature of roles will clarify where the political struggle for partisan control is strongest.

\section{FINAL CONSIDERATIONS}

In this article, we presented some indicators and trends on the party affiliation of appointees to DAS positions in the federal bureaucracy.

The moderate percentage of party-affiliated mid-ranking (12\%) and top-level (below 30\%) positions suggests a low degree of control of political-party identity among the appointees. Those nominated for DAS positions without ties to the public sector have a higher percentage of affiliates.

Our analysis reveals that presidents - and their parties - have adopted different strategies for dividing administrative power. In PT administrations there was a higher average percentage of affiliates in positions within the ruling bureaucracy and greater concentration of affiliates in the presidential party, compared to Cardoso's second term and the Temer government. In addition to potential 
differences in government strategies, there may be differences in the programmatic, organizational, and action strategies of the major parties that have ruled the country since the late 1990s.

We argue that the data on affiliation nomination in the middle and upper echelons of federal bureaucracy are a relevant source of information about party influence on selections, but only one of many possible links - although the most explicit - between appointees and parties. Alternative paths to formal affiliation may be a more relevant instrument of tiess between appointors and appointees, such as professional and friendship networks.

Higher affiliation rates or greater partisanization in upper level bureaucracy are not intrinsically undesirable. They can enhance intersectoral coordination in agendas led by the center of government, notably the Presidency of the Republic. In any case, understanding how the power of the governing bureaucracy is divided, in an increasingly fragmented system, represents a step towards providing greater intelligibility to coalition management strategies in each government and for identifying how they affect the president's success in the legislative arena. 


\section{REFERENCES}

Almeida, A. (2018). Banco de dados de ministros, coalizões e gabinetes no Brasil 1985-2018. Brasília, DF: Instituto de Pesquisa Econômica Aplicada.

Ames, B. (1995). The deadlock of democracy in Brazil. Ann Arbor, MI: University of Michigan Press.

Amorim, O., Neto. (2000). Gabinetes presidenciais, ciclos eleitorais e disciplina legislativa no Brasil. Dados, 3(43), 479-519.

Amorim, O., Neto. (2019). Cabinets and coalitional presidentialism. In B. Ames (Ed.), Handbook of Brazilian politics (pp. 293-312). New York, NY: Routledge.

Barberia, L., \& Praça, S. (n.d.). Who gets political appointments? Partyloyalty and bureaucratic expertise in Brazil. Retrieved from https://cienciapolitica.org. br/system/files/documentos/eventos/2017/03/whogets-political-appointments-party-loyalty-and.pdf

Barbosa, K., \& Ferreira, F. (2019, January). Occupy government: democracy and the dynamics of personnel decisions and public finances (NBER Working Paper No. 25501). Retrieved from https://www.nber.org/ papers/w25501

Bertholini, F., \& Pereira, C. (2017). Pagando o preço de governar: custos de gerência de coalizão no presidencialismo brasileiro. Revista de Administração Pública, 51(4), 528-550.

Calvo, E., Guarnieri, F., \& Limongi, F. (2015). Why coalitions? Party system fragmentation, small party bias, and preferential vote in Brazil. Electoral Studies, 39, 219-229.

Cavalcante, P., \& Lotta, G. (Orgs.). (2015). Burocracia de médio escalão: perfil, trajetória e atuação. Brasília, DF: Escola Nacional de Administração Pública.

Codato, A., Dantas, E., Aguiar, E. M., Júnior, \& Calabrez, F. (2018). Prosopografia dos ajudantes do Ministério da Fazenda: uma análise das lógicas de recrutamento, dos itinerários profissionais e do perfil social do segundo escalão. In Anais do 410 Encontro da Associação Nacional de Pós-Graduação e Pesquisa em Ciências Sociais. Caxambu, MG.

D’Araujo, M. C., \& Lameirão, C. (2010). A elite dirigente do governo Lula. Rio de Janeiro, RJ: Ed. FGV.
D’Araújo, C.; \& Lameirão, C. (2011). Dirigentes públicos federais de alto escalão no governo Lula. In R. Nogueira, \& J. C. Cardoso, Jr. (Eds.), Burocracia e ocupação no setor público brasileiro (pp. 91-131). Brasília, DF: Instituto de Pesquisa Econômica Aplicada.

D’Araujo, M. C., \& Petek, J. (2018). Recrutamento e perfil dos dirigentes públicos brasileiros nas áreas econômicas e sociais entre 1995 e 2012. Revista de Administração Pública, 52(5), 840-862.

Decreto n. 5.497, de 21 de julho de 2005. (2005). Dispõe sobre o provimento de cargos em comissão do Grupo-Direção e Assessoramento Superiores - DAS, níveis 1 a 4, por servidores de carreira, no âmbito da administração pública federal. Brasília, DF.

Decreto n. 9.021, de 31 de março de 2017. (2017). Altera o Decreto n. 5.497, de 21 de julho de 2005, que dispõe sobre o provimento de cargos em comissão do Grupo-Direção e Assessoramento Superiores - DAS, níveis 1 a 4, por servidores de carreira, no âmbito da administração pública federal. Brasília, DF.

Franz, P., \& Codato, A. (2018). Estabilidad y inestabilidad ministerial en el presidencialismo brasileño. In A. Codato, \& F. Espinoza (Ed.), Élites en las Américas: diferentes perspectivas (pp. 319-345). Curitiba, PR: Ed. UFPR.

Gailmard, S., \& Patty, J. (2007). Slackers and zealot: civil service, policy discretion, and bureaucratic expertise. American Journal of Political Science, 51(4), 873-889.

Gerring, J. (2012). Mere description. British Journal of Political Science, 42(4), 721-746.

Grindle, M. (2012). Jobs for the boys: patronage and the State in comparative perspective. Cambridge, MA: Harvard University Press.

Guedes, B. (1994). Politician's dilemma: building State capacity in Latin America. Berkeley, CA: University of California Press.

Hammond, T., \& Knott, J. (1996). Who controls the bureaucracy? Presidential power, congressional dominance, legal constraints, and bureaucratic autonomy in a model of multi-institutional policymaking. The Journal of Law, Economics, and Organization, 12(1), 119-166. 
Kopecký, P., Mair, P., \& Spirova, M. (Eds.). (2012). Party patronage and party government in European democracies. Oxford, England: Oxford University Press.

Kopecký, P., Meyer-Sahling, J. H., Panizza, F., Scherlis, G., Schuster, C., \& Spirova, M. S. (2016). Party patronage in contemporary democracies: results from an expert survey in 22 countries from five regions. European Journal of Political Research, 55, 416-431.

Lameirão, C. (2011a). A ordenação dos cargos de direção e assessoramento superiores (DAS) como estratégia para o fortalecimento institucional e decisório do presidente da República. In J. Cardoso, Jr., \& R. Pires (Orgs.), Gestão pública e desenvolvimento: desafios e perspectivas (pp. 175198). Brasília, DF: Instituto de Pesquisa Econômica Aplicada.

Lameirão, C. (2013). A Casa Civil como estrutura de poder e controle da Presidência: gênese, trajetória e o seu desenvolvimento institucional no governo FHC. (Doctoral Dissertation). Universidade Federal Fluminense, Niterói, RJ.

Lameirão, C. (2015). Os níveis de controle da presidência sobre a coordenação governamental e a coalizão partidária (1995-2010). In F. Lopez (Ed.), Cargos de confiança no presidencialismo de coalizão brasileiro (pp. 165-208). Brasília, DF: Instituto de Pesquisa Econômica Aplicada.

Lewis, D. (2008). The politics of presidential appointments: political control and bureaucratic performance. Princeton, NJ: Princeton University Press.

Lopez, F. (2015). Evolução e perfil dos nomeados na administração pública federal (1999-2014) (Nota Técnica n. 16). Brasília, DF: Instituto de Pesquisa Econômica Aplicada.

Lopez, F., Bugarin, M. \& Bugarin, K. (2015). Mudanças político-partidárias e rotatividade dos cargos de confiança. In F. Lopez (Org.), Cargos de confiança no presidencialismo de coalizão (pp. 33-70). Brasília, DF: Instituto de Pesquisa Econômica Aplicada.

Lopez, F., \& Praça, S. (2015). Critérios e lógicas de nomeação para o alto escalão da burocracia federal brasileira. In F. Lopez (Ed.), Cargos de confiança no presidencialismo de coalizão brasileiro (pp. 107138). Brasília, DF: Instituto de Pesquisa Econômica Aplicada.
Lopez, F., \& Praça, S. (2018). Cargos de confiança e políticas públicas no Executivo federal. In R. Pires, G. Lotta, \& V. E. Oliveira (Orgs.), Burocracia e políticas públicas no Brasil: interseções analíticas (pp. 141-160). Brasília, DF: Instituto de Pesquisa Econômica Aplicada.

Lopez, F., \& Silva, T. (2019). O carrossel burocrático nos cargos de confiança da burocracia federal: análise de sobrevivência dos nomeados para cargos de direção e assessoramento superio (1999-2016) (Manuscrito não publicado).

Loureiro, M., Abrucio, F., \& Rosa, C. (1998). Radiografia da alta burocracia brasileira: o caso do Ministério da Fazenda. Revista do Serviço Público, 49(4), 46-82.

Mainwaring, S. (1991). Politicians, parties, and electoral systems: Brazil in comparative perspective. Comparative Politics, 24(1), 21-43.

Mauerberg, A. (2016). Cabinet composition and assessment of a multiparty presidential system (Ph.D. Thesis). São Paulo, SP: Fundação Getulio Vargas.

Mikkelsen, K. (2018). Old habits die hard, sometimes: history and civil service politicization in Europe. International Review of Administrative Sciences, 84(4), 803-819.

Nexo. (2018, 13 de julho). A genealogia e o perfil dos partidos brasileiros. Retrieved from https:// www.nexojornal.com.br/especial/2018/07/16/Agenealogia-e-o-perfil-dos-partidos-brasileiros

Nogueira, R., \& Cardoso, J., Jr. (Eds.). (2011). Burocracia e ocupação no setor público brasileiro. Brasília, DF: Instituto de Pesquisa Econômica Aplicada.

Nunes, E. (1997). A gramática política do Brasil: clientelismo e insulamento burocrático. Brasília, DF: Escola Nacional de Administração Pública.

Olivieri, C. (2007). Política, burocracia e redes sociais: as nomeações para o alto escalão do Banco Central do Brasil. Revista de Sociologia e Política, 29, 147-168.

Pacheco, R. (2010). O debate sobre dirigentes públicos: atores, argumentos e ambiguidades. In F. Abrucio, M. Loureiro, \& R. Pacheco (Orgs.), Burocracia e política no Brasil: desafios para o Estado democrático no século XXI (pp. 277-306). São Paulo, SP: Ed. FGV. 
Page, E., \& Wright, V. (Eds.). (1999). Bureaucratic elites in Western European States: a comparative analysis of top officials. Oxford, England: Oxford University Press.

Painter, M., \& Peters, G. (Eds.). 2011. Tradition and public administration. London, England: PalgraveMacMillan.

Pereira, C., Batista, M., Praça, S., \& Lopez, F.. (2017). Watchdogs in our midst: how presidents monitor coalitions in Brazil's multiparty presidential regime. Latin America Politics and Society, 59(3), 27-47.F

Pereira, C., \& Bertholini, F. (2019). Coalition management in multiparty presidential regimes. In B. Ames (Ed.), Handbook of Brazilian Politics (pp. 313-330). New York, NY: Routledge.

Peters, G. (1999). La politica de la burocracia. Mexico, DF: Fondo de Cultura Económica.

Peters, G., \& Pierre, J. (Eds.). (2004). Politicization of the civil service in comparative perspective: the quest for control. New York, NY: Routledge.
Praça, S., Freitas, A., \& Hoepers, B. (2011). Political appointments and coalition management in Brazil, 2007-2010. Journal of Politics in Latin America, 3(2), 141-172.

Praça, S., \& Lopez, F. (2019). Political appointments, political parties and bureaucracy. In B. Ames (Ed.), Handbook of Brazilian politics (pp. 358-370). New York, NY: Routledge.

Raile, E., Pereira, C., \& Power, T. (2011). The executive toolbox: building legislative support in multiparty presidential regime. Political Research Quarterly, 64(2), 323-334.

Tribunal Superior Eleitoral. (n.d.). Relação de filiados. Retrieved from http://www.tse.jus.br/ partidos/filiacao-partidaria/relacao-de-filiados

Weber, M. (2002). Economia e sociedade. Brasília, DF: Ed. UnB.

Yesilkagit, K., \& Van Thiel, S. (2008). Political influence and bureaucratic autonomy. Public Organization Review, 14, 137-153.

\section{Felix G. Lopez}

https://orcid.org/0000-0003-4725-4473

$\mathrm{PhD}$ in Sociology and Researcher at the Directorate of Studies on State, Institutions and Democracy at the Institute of Applied Economic Research (Diest/Ipea). E-mail: felixglopez@gmail.com

\section{Thiago Moreira da Silva}

https://orcid.org/0000-0001-8451-8621

$\mathrm{PhD}$ in Political Science and Postdoctoral Researcher at the Institute of Social and Political Studies of the Rio de Janeiro State University (IESP-UERJ).E-mail: thiagomoreira@iesp.uerj.br 